\title{
Characteristics and Distribution of Potato Latent Carlavirus (Red LaSoda Virus) in North America
}

Robert W. Goth, Research Plant Pathologist, USDA/ARS, Plant Sciences Institute, Vegetable Laboratory, Beltsville, MD 20705; Peter J. Ellis, Laboratory Director, Phyto Diagnostics Company Limited, 8801 East Saanich Rd., Sidney, BC, Canada V8L 1H3; Gerda de Villiers, Plant Virologists, Phyto Diagnostics Company Limited, Sidney, BC, Canada V8L 1H3; E. W. Goins, Biological Science Technician, USDA/ARS, Plant Sciences Institute, Vegetable Laboratory, Beltsville, MD 20705; and N. S. Wright, Plant Virologists, Phyto Diagnostics Company Limited, Sidney, BC, Canada V8L 1H3

\begin{abstract}
Goth, R. W., Ellis, P. J., de Villiers, G., Goins, E. W., and Wright, N. S. 1999. Characteristics and distribution of potato latent carlavirus (Red LaSoda virus) in North America. Plant Dis. 83:751-753.

A carlavirus (code name RLSV and subsequently named potato latent carlavirus, PotLV) with serological and biological characteristics different from those of potato $\mathrm{M}$ carlavirus (PVM) and potato S carlavirus (PVS) was detected in the potato (Solanum tuberosum) cultivar Red LaSoda by the Scottish Agricultural Science Agency in 1992. During a routine electron microscope testing of accessions in the Vancouver Collection of Virus-Free Potatoes growing in the California winter test in 1993, a filamentous rod-shaped virus similar to PVS and PVM was found in a Red LaSoda clone from Nebraska. The virus was isolated and purified. The monoclonal antibody, MAb 4E12, which is highly specific to the PotLV virus, was developed. From 1994 to 1998, the accessions in the Vancouver Collection of Virus-Free Potatoes were assayed by triple antibody sandwich enzyme-linked immunosorbent assay (TAS-ELISA) using the 4E12 MAb. Seven accessions tested from 1994 to 1996 were infected with PotLV. None of the 270 and 267 accessions in this collection tested positive for this virus in 1997 and 1998, respectively. In 1997 and 1998, the 137 accessions in the U.S. National Varietal Collection maintained at Presque Isle, Maine, were also assayed using the 4E12 MAb. The cultivars High Plains, Platte, and Red LaSoda were the only accessions that tested positive for PotLV. Nicotiana benthamiana, $N$. megalosiphon, and $N$. occidentalis are new systemic hosts for PotLV. TAS-ELISA with the 4E12 $\mathrm{MAb}$ is now part of the standardized test for PotLV in Canada.
\end{abstract}

In 1992, the Scottish Agricultural Science Agency discovered a symptomless carlavirus (code name RLSV) in an accession of the potato (Solanum tuberosum L.) cultivar Red LaSoda imported from the United States (3). The virus was named potato latent carlavirus, PotLV (2). It is systemic in Nicotiana tabacum, N. rustica, and Physalis floridana (3), which are resistant to commonly occurring potato $\mathrm{S}$ carlavirus (PVS) and potato $\mathrm{M}$ carlavirus (PVM) (4).

This paper describes methods used to purify and develop monoclonal antibodies (MAbs) for the filamentous rod-shaped virus found by N. S. Wright in Red LaSoda plants grown in California. It reports on the distribution of PotLV in the U.S. National Varietal Collection at Presque Isle, Maine,

Corresponding author: Robert W. Goth

E-mail: rgoth@asrr.arsusda.gov

Accepted for publication 30 April 1999.

Publication no. D-1999-0601-02R

This article is in the public domain and not copyrightable. It may be freely reprinted with customary crediting of the source. The American Phytopathological Society, 1999. and describes new systemic herbaceous hosts for this virus. A preliminary report on this research has been presented (7).

\section{MATERIALS AND METHODS}

Propagation and purification of RLSV. PotLV was propagated in S. tuberosum cv. Red LaSoda. Plants used for serological testing and virus purification were obtained from infected tubers and were grown in a greenhouse at 18 to $22^{\circ} \mathrm{C}$ with a 12-h photoperiod. The method described by Leiser and Richter (8) was used to purify PotLV from systemically infected Red LaSoda leaves.

Electron microscopy. Sap was diluted 1:10 with $0.06 \mathrm{M}$ Sorensen's buffer, $\mathrm{pH}$ 6.8. To separate the particles, $10 \mu \mathrm{l}$ of Tween 20 was added to the diluted sap. This dilution was applied to carbon coated Maxtaform HR27 $3.05 \mathrm{~mm} \mathrm{Cu} / \mathrm{Rh}$ grids and kept at $21^{\circ} \mathrm{C}$ for $15 \mathrm{~min}$. The grids were stained with $2 \%$ phosphotungstate, $\mathrm{pH} 7.0$, dried, and observed at a magnification of $\times 30,000$ at an accelerating potential of $80 \mathrm{kV}$ using a Hitachi 7000 electron microscope. The microscope was calibrated with catalase and tobacco mosaic virus particles. The particle lengths were measured from enlarged photomicrographs.
Production of antibodies to PotLV. The purified virus $(1 \mathrm{mg} / \mathrm{ml})$ was emulsified with Freund's complete (primary injection) or incomplete (subsequent injections) adjuvant (1:1 vol/vol). New Zealand white rabbits were given a primary intramuscular injection and two subsequent intramuscular injections at monthly intervals. Following the third injection, blood was collected six times at 2-week intervals.

The immunoglobulin (IgG) fraction was isolated from the whole serum by affinity chromatography on a Protein G-Sepharose (Pharmacia, Montreal) column followed by elution with $1.0 \mathrm{mM}$ acetic acid. This was immediately neutralized with $1.0 \mathrm{M}$ Tris$\mathrm{HCl}, \mathrm{pH}$ 9.0, precipitated with an equal volume of saturated ammonium sulfate, and incubated overnight at $4^{\circ} \mathrm{C}$. Immunoglobulins were collected by centrifugation at $10,000 \times g$ for $20 \mathrm{~min}$, and the pellet was resuspended in phosphate-buffered saline (PBS) (127 mM NaCl, $2.6 \mathrm{mM} \mathrm{KCl}$, $8.5 \mathrm{mM} \mathrm{Na}_{2} \mathrm{H}_{2} \mathrm{PO}_{4}$, and $1.1 \mathrm{mM} \mathrm{K \textrm {K } _ { 2 }} \mathrm{PO}_{4}$, $\mathrm{pH}$ 7.4). The immunoglobulins were adjusted to $1 \mathrm{mg} / \mathrm{ml}\left(A_{280 \mathrm{~nm}}=1.4 \mathrm{OD}\right)$ and stored in $0.5-\mathrm{ml}$ aliquots at $-20^{\circ} \mathrm{C}$.

Production of hybridomas and monoclonal antibodies. BALB/c mice were immunized with a minimum of three intraperitoneal injections, each consisting of $100 \mu \mathrm{g}$ of freshly prepared virion administered without adjuvant. Following the first injection, a second was given 3 to 4 weeks later, and a third 2 to 3 weeks after the second. Five days after the third injection, a mouse was killed and its spleen harvested. The fusion procedure was as described by Ellis and Wieczorek (6). The fusion products were dispensed into eight 96-well plates. Five days after plating, the wells were examined for hybridoma colonies. Culture fluids from the wells were tested against infected and healthy sap by triple antibody sandwich enzyme-linked immunosorbent assay (TAS-ELISA). Those hybridoma cell lines that produced antibodies that tested positive with PotLV and negative with healthy plant sap were cloned twice by limiting dilution. The cloned hybridomas were grown in cell culture, and the supernatants were tested against the following panel of viral antigens: PotLV-BC, isolated from cv. Red 
LaSoda plants from the Vancouver Collection of Virus-Free Potatoes; PotLV-MN, isolated from Red LaSoda plants grown in Minnesota and provided by Willem Schrage; PVS-BC, a potato $\mathrm{S}$ carlavirus isolate maintained as a standard at Vancouver; PVS-An, an isolate of the Andean strain (9) of potato S carlavirus; and PVM, an isolate of potato $M$ carlavirus maintained as standard at Vancouver. Nine hybridomas that produced antibodies either (i) specific for both isolates of PotLV and showing almost no reaction with the heterologous virus antigens in the panel, (ii) cross-reacting with PotLV and PVS-An, or (iii) reacting with both PotLV isolates, PVS, PVS-An, and PVM, were selected for future use. Two hybridomas that produced antibodies with high titer in culture fluid, MAb 4E12 and 6H11, respectively, were selected for subclass determination and ascites fluid production. The isotypes of the MAbs were determined by double antibody sandwich enzyme-linked immunosorbent assay (DAS-ELISA) using a mouse hybridoma isotyping kit (Calbiochem, Behring Diagnostics, La Jolla, CA) following the manufacturer's protocol. Ascitic fluid was prepared and stored as described by Ellis and Wieczorek (6).

ELISA. An indirect TAS-ELISA procedure was used to test the reactivity of the antibodies secreted by the various hybridoma colonies (5). All reagents were used at $100 \mu \mathrm{g}$ per well in flat-bottom microtiter plates (Corning, Corning, NY), except the blocking steps, which were at $300 \mu \mathrm{l}$ per well. The plates were coated and held overnight at $4^{\circ} \mathrm{C}$ with rabbit anti-PotLV immunoglobulins at $1 \mu \mathrm{g} / \mathrm{ml}$ in PBS. Plates were blocked with $0.2 \%$ nonfat milk powder in PBS (wt/vol) for $30 \mathrm{~min}$ at room temperature. Leaf tissues, $0.1 \mathrm{~g}$ of virusinfected and virus-free Red LaSoda, were ground in a sap extractor (Pollähne, Wennigsen, Germany) with $0.9 \mathrm{ml}$ of PBS containing $0.05 \%$ Tween 20 and $0.2 \%$ nonfat milk powder (PBS-T-M). Extracts were incubated in the wells overnight at $4^{\circ} \mathrm{C}$. The plates were washed three times for $20 \mathrm{~s}$ with deionized distilled water. Culture fluid containing MAbs was diluted $(1: 10 \mathrm{vol} / \mathrm{vol})$ in PBS-T-M, then added to the wells and incubated at room temperature for $3 \mathrm{~h}$. After washing as above, goat anti-mouse phosphatase conjugate (Jackson Immunoresearch Laboratories, Avondale, PA), diluted (1:5,000 vol/vol) in PBS-T-M, was added to the wells and incubated for 2 $\mathrm{h}$ at room temperature. After washing, a substrate ( $p$-nitrophenyl phosphate at 0.5 $\mathrm{mg} / \mathrm{ml}$ in $10 \%$ diethanolamine, $\mathrm{pH} 9.8$ ) was added to the test wells and incubated in the dark for $2 \mathrm{~h}$ at $23^{\circ} \mathrm{C}$. ELISA absorbance values were measured at $A_{405 \mathrm{~nm}}$ with a Dynatech MR5000 plate reader (Dynatech Laboratories, Chantilly, VA).

Plant inoculation. Bioassay indicator plants were grown from seed in Jiffy Mix at 19 to $24^{\circ} \mathrm{C}$ in a greenhouse with a $16-\mathrm{h}$ light period. Plants were inoculated by rubbing silicon carbide-dusted leaves with sap from infected Red LaSoda plants. Fourteen days later, a composite sample of

Table 1. Reactivity of monoclonal antibodies produced by immunization of BALB/c mice with potato latent virus ${ }^{\mathrm{a}}$

\begin{tabular}{lcccccc}
\hline MAb & PotLV-BC & PotLV-MN & PVS & PVS-An & PVM & Virus-free \\
\hline IBII & +++ & +++ & ++ & +++ & +++ & - \\
2D12 & +++ & ++ & + & +++ & +++ & - \\
3B5 & +++ & +++ & - & ++ & - & - \\
4B2 & +++ & +++ & - & ++ & ++ & - \\
4E12 & +++ & +++ & - & - & - & - \\
5H2 & +++ & +++ & - & ++ & - & - \\
6H11 & +++ & +++ & - & ++ & ++ & - \\
6E12 & +++ & +++ & - & ++ & - & - \\
\hline
\end{tabular}

${ }^{\text {a }}$ Reactivity was determined using the triple antibody sandwich enzyme-linked immunosorbent assay (TAS-ELISA) after 2-h incubations with the substrate. ELISA reactions were scored $+++>1.0,++$ $=0.5$ to 1.0 , and $+<0.5$ but greater than three times the readings of the extracts of virus-free control plants. Values below this threshold were scored - for negative.

Table 2. Reaction of plants inoculated with potato latent carlavirus (PotLV), potato $S$ carlavirus (PVS), and potato M carlavirus (PVM) as determined by triple antibody sandwich enzyme-linked immunosorbent assay (TAS-ELISA) using monoclonal antibody 4E12 for PotLV and double antibody sandwich (DAS)-ELISA for PVS and PVM

\begin{tabular}{lccc}
\hline & \multicolumn{3}{c}{ Virus } \\
\cline { 2 - 4 } Host plant & PotLV & PVS & PVM \\
\hline Nicotiana debneyi & Systemic $^{\mathrm{a}}$ & Systemic $^{\mathrm{a}}$ & Systemic $^{\mathrm{b}}$ \\
N. glutinosa & Systemic $^{\mathrm{a}}$ & None $^{\mathrm{a}}$ & Systemic $^{\mathrm{a}}$ \\
N. benthamiana & Systemic & Systemic $^{\mathrm{b}}$ & Systemic $^{\mathrm{c}}$ \\
N. megalosiphon & Systemic & None & None $^{\mathrm{a}}$ \\
N. occidentalis & Systemic & None & Systemic \\
\hline
\end{tabular}

${ }^{\text {a }}$ Reaction similar to those previously reported by Brattey et al. (3).

${ }^{\mathrm{b}}$ Reaction similar to those previously reported by Beck et al. (1).

${ }^{c}$ Reaction similar to those previously reported by Brunt et al. (4). three leaves from each plant was assayed for PotLV by TAS-ELISA. Plants of the potato cultivars were from seed pieces of virus-tested seed stocks. Seed pieces were planted in Jiffy Mix in 20-cm plastic pots. Leaves of plants 20 to $30 \mathrm{~cm}$ tall were dusted with 600-mesh silicon carbide and rubbed with sap obtained from infected Red LaSoda plants. Thirty days after inoculation, a composite sample of three uninoculated leaves from each plant was assayed for PotLV by TAS-ELISA. Samples of each cultivar accession in the U.S. National Varietal Collection consisted of composite leaf samples from the sixth to the eighth node of at least five plants.

\section{RESULTS AND DISCUSSION}

Purified virus particles are straight or slightly curved. One hundred twelve virions ranged in length from 600 to $720 \mathrm{~nm}$, with a mean size of $690 \mathrm{~nm}$.

The 4E12 MAb was specific to PotLV when tested against the isolates of three carlaviruses (Table 1). The Andean strain of PVS shared the greatest number of epitopes with PotLV (Table 1). This monoclonal antibody is now used routinely by the Canadian Food Inspection Agency to test nuclear seed stocks.

Seven additional cultivar accessions in the Vancouver Collection of Virus-Free Potatoes tested positive for PotLV from 1994 to 1996: in 1994, Pembina Chipper and Pungo; in 1995, Kanona and Red Pontiac; and in 1996, Purple Chief, Denali, and Tejon. The PotLV was not detected in 270 and 267 cultivars tested in 1997 and 1998, respectively.

When field samples from the 137 cultivars in the U.S. National Varietal Collection were tested in June 1997 and 1998 by TAS-ELISA, only High Plains, Platte, and Red LaSoda were positive for PotLV. This germ plasm is maintained in the repository and is available only upon request.

PotLV was mechanically transmitted to all of five plants of the potato cultivars Denali, Ranger Russet, Russet Norkotah, and Red LaSoda derived from virus-free stem cutting. However, we were unable to detect transmission of PotLV to 134 other cultivars in the collection that were mechanically inoculated. In addition to the Nicotiana spp. previously reported as hosts of PotLV (3), this virus was mechanically transmitted to $N$. benthamiana, N. megalosiphon, and N. occidentalis (Table 2).

This study shows that PotLV has been present in Red LaSoda grown in the United States and Canada since 1993. Our data suggest that PotLV may be present in additional seed stock cultivars in North America, but it remains undetected or unidentified because infected plants are symptomless or were incorrectly diagnosed by previous assay procedures as infected with PVS.

Information and antibodies produced in this study can be used to develop protocols 
and assays to ensure that neither of these misinterpretations occur. This will help verify the virus-free status of seed stocks required for the nuclear seed class of the limited generation seed systems in North America and meet the importation standards for potatoes in other countries.

\section{LITERATURE CITED}

1. Beck, D. L., Van Dolleweerd, C., Lough, T., Balmori, E., Voort, M., Andersen, I., O'Brien, E., and Forester, R. 1994. Disruption of virus movement confers broad-spectrum resistance against systemic infection by plant viruses with a triple gene block. Proc. Natl. Acad. Sci. USA 91:10310-10314.

2. Brattey, C., George, E., Goodfellow, H., Jef- fries, C., McDonald, J., Badge, J., and Foster, G. 1998. A newly described carlavirus infecting potato. Abstract 1. 11.33. Offered Abstr. Vol. 2. International Congress of Plant Pathology 1998, Edinburgh, Scotland.

3. Brattey, C., Jeffries, C., Goodfellow, S., Rose, G., Burns, R., and George, E. 1995. Some characteristics of a virus infecting Solanum tuberosum cv. Red La Soda imported from the USA. Pages 65-69 in: Proc. EAPR Virology Section Meeting Bled., 9th.

4. Brunt, A., Crabtree, K., Dallwitz, M., Gibbs, A., and Watson, L., eds. 1997. Viruses of Plants Descriptions and Lists for the VIDE Database. CAB International, Wallingford, UK. pp. 10181024.

5. Converse, R. H., and Martin, R. R. 1990. ELISA methods for plant viruses. Pages 179196 in: Serological Methods for Detection and
Identification of Viral and Bacterial Plant Pathogens. R. Hampton, E. Ball, and S. De Boer, eds. American Phytopathological Society, St. Paul, MN

6. Ellis, P. J., and Wieczorek, A. 1992. Production of monoclonal antibodies to beet western yellows virus and potato leafroll virus and their use in luteovirus detection. Plant Dis. 76:75 78.

7. Goth, R. W., and Goins, E. W. 1998. Distribution of Carlavirus Red LaSoda (RLSV). Am. J Potato Res. 75:277.

8. Leiser, R. M., and Richter, J. 1978. Reiningung und einige Eigenshafter des Kartoffel Y virus. Arch. Phytopathol. Pflanzenschutz. 14:337 350.

9. Slack, S. A. 1983. Identification of an isolate of the Andean strain of potato virus $S$ in North America. Plant Dis. 67:786-789. 